Pobrane z czasopisma Annales $\mathrm{H}$ - Oeconomia http://oeconomia.annales.umcs.pl

Data: 26/04/2023 15:13:06

DOI:10.17951/h.2015.59.3.91

\begin{tabular}{lcc}
\hline \multicolumn{3}{c}{ A N N A L E S } \\
UNIVERSITATIS MARIAE CURIE-SKŁODOWSKA \\
LUBLIN - POLONIA \\
VOL. XLIX, 3 & SECTIOH \\
\hline
\end{tabular}

Pope John Paul II State School of Higher Education in Biała Podlaska, Department of Economics and Management $\backslash$ Division of Finance and Accounting

Pope John Paul II State School of Higher Education in Biała Podlaska, Department of Physical Education and Physiotherapy $\backslash$ Division of Tourism and Recreation

\author{
MAREK KUŹMICKI \\ MALGORZATA WASILEWSKA
}

m.kuzmicki@dydaktyka.pswbp.pl,m.wasilewska@dydaktyka.pswbp.pl

\title{
The Image of Poland as a Tourist Destination in the Country's Main Economic Partners
}

Wizerunek Polski jako destynacji turystycznej w krajach głównych partnerów gospodarczych

Keywords: image, Poland, tourist destination.

Slowa kluczowe: wizerunek, Polska, destynacja turystyczna.

JEL Code: F29

\section{Introduction}

Market analysts assume that tourism will become the largest global industry. Emerging economies, including Poland, will be the driving force for tourism in the current decade (Analiza wyników badań wizerunku Polski, 2008, p. 3). Stereotypes about a place are of a great importance in the selection of the tourist destination ${ }^{1}$ by

1 Tourist destination is a tourist's travel destination. It is treated as a space (e.g. locality, region, large hotel) that tourist selects (or segment of tourism) as his/her destination. It contains the necessary facilities during the stay, allowing accommodation, meals, entertainment or other activities. It is a product which is subject to the laws of competition, which makes it necessary to adopt a certain action strategy; Bieger T., Management von Destination und Tourismusorganisation. - 2 Aufl. München, Wien/A 1997. 
foreign tourists. The condition for the revival of foreign tourist traffic to Poland is to create a positive country's image ${ }^{2}$ in the international arena.

In accordance with the Law of 4 September 1997 on government administration departments (Act of 4 September 1997) responsibility for the promotion of Poland and Polish language abroad rests with the Minister of Foreign Affairs. At the same time, Polish Tourist Organisation ${ }^{3}$, which in October 2008 presented Poland's Marketing Strategy in the tourism sector for the years 2008-2015, is responsible for the promotion of Poland in the context of tourism. The document outlines, among others things, basic assumptions of tourism promotion strategy, competitive analysis, and the importance of Poland as a tourist destination (Badania wizerunkowe Polski, 2011, p. 24). In the same year, the Council for the Promotion of Poland was reactivated at the Ministry of Foreign Affairs and a document called Directions for the Promotion of Poland until 2015 was presented in 2010 (Szmit, 2010, p. 123).

The aim of the study is to determine the current image and reputation of Poland in countries covered by the research of the Ministry of Economy, particularly important from an economic point of view, i.e. France, Spain, the Netherlands, Germany, the USA, Russia, Ukraine, United Kingdom, Italy. Poland's image research carried out by the Polish public and private institutions will be used to achieve the aim of the article. Content included in the article emphasizes not only the current opinion on Poland's image, but also changes in perceiving the country that have occurred in recent years.

\section{Studies of the Polish Brand Institute}

In the expert report carried out at the request of the Polish Tourist Organisation in 2008, „Analiza wyników badań wizerunku Polski i postrzegania polskiej marki na świecie. Założenia i rekomendacje do pozycjonowania Polski jako kraju docelowego podróży turystycznych na lata 2009-2015" Poland has been described as a country without a clear and coherent image abroad. Simultaneously, it is associated with a hospitable, beautiful country, with culture and good food, at the same time cheap and safe. Cities are Poland's assets. Polish people are considered to be

2 The image of a country which is a synthesis of the subjective knowledge of what we know about the country, including the accompanying emotions. The country's image is shaped by various factors, which need not be linked to an objective assessment of the situation in the country based on precise criteria; Gorbaniuk O., Radman D., Struktura wizerunku kraju i jej pomiar, Studia Socjologiczne 2011, 4 (203).

3 Polish Tourist Organisation operates under the Act of 25 June 1999 on the Polish Tourist Organization. The Polish Tourist Organisation is a state legal entity. The minister of tourism exercises supervision over the Polish Tourist Organisation. Its main goal is to strengthen the promotion of Poland in the field of tourism in the country and abroad. The Polish Tourist Organisation creates the conditions for cooperation between government, local government, and business associations in the field of tourism, including economic and professional self, and associations active in this field; The Act of 25 June 1999 on the Polish Tourist Organisation (Journal of Laws of 1999, No. 62, item 689). 
a hard-working nation. The wealth of history and culture are highlighted. Poland is seen as a Western country, with a Slavic soul. During the years 2006-2008, Poland was not a fashionable country. It was seen as a tourist destination with a little "lowend", among other things, because there were not organized any interesting events and entertainment (Badania wizerunkowe Polski, 2011, pp. 27-28).

\section{Studies of the Polish Tourist Organization}

For the purposes of Poland's Marketing Strategy in the tourism sector for 20082015 PTO conducted a study of recognition in 7 destination countries for Polish branded products and services placement, and countries with the greatest potential to invest in Poland (France, the Netherlands, Germany, USA, Russia, Ukraine, and Italy $)^{4}$. The representatives of the tourism industry were the largest group of participants (511 people) of the research conducted in 2008. Their associations with Poland were (Badania wizerunkowe Polski, 2011, p. 31):

- France: Cracow; Warsaw; cultural richness; John Paul II; beautiful, quiet, interesting, nice country; history, World War II; Chopin;

- the Netherlands: nice country; agricultural landscape, nature; culture, cities;

- Germany: nature, wildlife, primeval forests, beauty, forests; neighbour, history; leave, holiday, sanatorium leave; culture; hospitality; Cracow; sea, beaches; Masuria;

- USA: communism, the country in Eastern Europe, the Solidarność movement; turbulent history, the Holocaust; Cracow; good food, good drink; religious monuments, shrines, John Paul II; landscapes, nature; Baltic maritime tourism, Gdańsk; culture, the city and its history, architecture;

- Russia: tours, leisure, tourism; cuisine, food, alcohol; castles; cities, architecture; Zakopane; Cracow;

- Ukraine: Cracow; Zakopane; mountains, skiing, mountain resorts; Europe, abroad; close, similar, neighbour; home, childhood, family;

- Italy: Cracow; John Paul II, faith, religion; cities of culture and art, culture; nature, landscapes, beautiful country; history, World War II; cuisine; Auschwitz; Warsaw; Eastern country, communism.

In order to develop a communication strategy on the UK, German, and French markets, studies on Poland's image quality were conducted among locals and tour operators from the countries of destination on request of the Polish Tourist Organisation. The results are given in Table 1.

4 See: Badania rozpoznawalności Polski na rynkach zagranicznych, Polska Organizacja Turystyczna, Warszawa 2008. 
Pobrane z czasopisma Annales $\mathrm{H}$ - Oeconomia http://oeconomia.annales.umcs.pl

Data: 26/04/2023 15:13:06

MAREK KUŹMICKI, MAŁGORZATA WASILEWSKA

Table 1. Associations with Poland in Germany, Great Britain and France

\begin{tabular}{|c|c|c|}
\hline Germany & Great Britain & France \\
\hline \multicolumn{3}{|c|}{ Positive associations } \\
\hline $\begin{array}{l}\text { - beautiful scenery - in } \\
\text { particular the Baltic Sea } \\
\text { (beautiful, wide beaches), } \\
\text { Masuria, Tatra Mountains } \\
\text { and Zakopane } \\
\text { - city - Warsaw, Cracow, } \\
\text { Gdańsk, Wrocław } \\
\text { - favorable prices } \\
\text { - positive feedback about } \\
\text { Poles: friendly, well- } \\
\text { educated, hard-working, } \\
\text { creative } \\
\text { - delicious cuisine: mostly } \\
\text { dumplings, sauerkraut-and- } \\
\text { meat stew (knowledge of } \\
\text { the Polish names of these } \\
\text { dishes), sausage }\end{array}$ & $\begin{array}{l}\text { - unspoiled natural areas, forests, } \\
\text { known as "untouched, unspoilt" } \\
\text { - rich history } \\
\text { - Polish products (sausage, vodka, } \\
\text { dumplings) } \\
\text { - Poles - earnest, good employees } \\
\text { - high economic potential of the } \\
\text { country }\end{array}$ & $\begin{array}{l}\text { - Pope John Paul II } \\
\text { - Lech Walesa and the Solidarność } \\
\text { movement } \\
\text { - Napoleon } \\
\text { - Chopin } \\
\text { - history and architecture } \\
\text { - capital - certainly interesting, but little } \\
\text { known } \\
\text { - the first country in the Eastern bloc to } \\
\text { open to Europe } \\
\text { - certainly a country with a rich culture } \\
\text { - authenticity, sincerity of people } \\
\text { - Catholic religion, strong faith, } \\
\text { patriotism } \\
\text { - many museums } \\
\text { - nightlife in the capital } \\
\text { - Cracow - a university town } \\
\text { - interesting cuisine, vodka }\end{array}$ \\
\hline \multicolumn{3}{|c|}{ Negative associations } \\
\hline $\begin{array}{l}\text { - car thefts } \\
\text { - lack of knowledge of } \\
\text { foreign languages among } \\
\text { Poles } \\
\text { - poor transport } \\
\text { infrastructure } \\
\text { - gray colour } \\
\text { - political tensions } \\
\text { - excessive attachment to } \\
\text { religion and tradition } \\
\text { - black market }\end{array}$ & $\begin{array}{l}\text { - gray, cold country } \\
\text { - the industrial architecture } \\
\text { - Catholic religion and attachment } \\
\text { to tradition } \\
\text { - uncomfortable living conditions } \\
\text { for residents } \\
\text { - nation ,closed” and not very } \\
\text { cosmopolitan }\end{array}$ & $\begin{array}{l}\text { - gray, sad, serious, little entertainment } \\
\text { - difficult economic conditions } \\
\text { - cold } \\
\text { - boring country } \\
\text { - poorly developed infrastructure } \\
\text { - assembly plants, heavy industry, } \\
\text { factories, mines } \\
\text { - images of war, ghettos, concentration } \\
\text { camps, postwar repression } \\
\text { - similar to the Russian landscape, not } \\
\text { very interesting, "the shadow of Russia" } \\
\text { - corruption } \\
\text { - "Polish plumber", }\end{array}$ \\
\hline
\end{tabular}

Source: Strategia komunikacji na rynkach: brytyjskim, niemieckim i francuskim. Diagnoza oraz raport z badań jakościowych, Ageron Polska i Ageron Internacional S.L. commissioned by the Polish Tourist Organization, Warszawa 2010, pp. 30-37

Studies have shown that Poland's image is difficult to determine and ambiguous. Poland is generally not seen as a tourist destination.

\section{Studies of the Institute of Public Affairs}

The Institute of Public Affairs (ISP), an independent research and analytical centre, conducts cyclical studies on Poland's and Polish people image in the world. Below there are presented the most important Polish stereotypes in the opinion of respondents from the three countries covered by the Ministry of Economy image research, i.e. Germany, France, and Ukraine. 
The study completed in Germany in 2008 provides a basis to conclude that Germans generally have a negative view of Poland. The most common was the association of Polish crime, including car theft. Others were: illegal work, taking workplaces, poverty, backwardness, unemployment, poor economy, unskilled workers. Among the most positive associations were: good prices, shopping, fast-growing country, economic growth, a member of the EU, a partner in Europe, nice scenery, holiday, culture, rich history, Polish cuisine, diligence, good workers, friendliness, and hospitality. People with higher education and those who live in the eastern German lands have a better opinion about Poland and Poles (Badania wizerunkowe Polski, 2011, p. 34).

Poland's image in France is changing. In 2000, Poland was treated as a peripheral and backward country, while in 2006 it began to be referred to as "making up" for the civilization delays and fast-growing. The French people spontaneously associated Poland with:

- (2000) - poverty, difficult life, unemployment, economic problems; Lech Walesa, the Solidarność movement, trade unions; catholic country, John Paul II; vodka, alcohol, drinking a lot, war, concentration camps (Warchala, 2001, p. 9),

- (2006) - entrance to the Union, a European country; poverty, unemployment, difficult life, economic problems; catholic country, John Paul II; Eastern country; war, concentration camps (Badania wizerunkowe Polski, 2011, p. 36).

The image of a typical Pole, who in the opinion of the French remains a diligent and religious person, has changed less.

Institute of Public Affairs also conducted studies on Poland's image in the Ukraine. Recent research results have been included in the report of 2013 (Poland-Ukraine, Poles-Ukrainians, Look Across the Border). Ukrainians associate Poland with the neighborhood, cooperation, proximity, and common Slavic roots. Poland in the eyes of Ukrainians is a fraternal, friendly, neighboring country, and Poles are seen as similar to Ukrainians, evoke sympathy, warm affection, and respect. Poland in the imagination of Ukrainians is perceived significantly better than Ukraine by Poles in such aspects of public life organization as: the presence of corruption, civil liberties, economic development, freedom of the media, and the level of bureaucracy (Fomina et al., 2013, pp. 53-56).

\section{TNS OBOP survey commissioned by PL.2012}

TNS OBOP examined the image of Poland and Poles in 13 European countries in 2009 at the request of PL.2012. In each country a representative sample constituted 1000 people aged 15 years and older.

Analysis of the characteristics attributed to Poland gave an opportunity to group the countries in terms of the image of Poland in the following groups (Badania wizerunkowe Polski, 2011, p. 39): 
1) France, United Kingdom, Germany, Austria, Norway, Spain, and the Netherlands - Poland is a little modern, a little backward, religious, agricultural, and focused mainly on the tradition and history.

2) Russia, Italy, Czech Republic - Poland is a country with a double face on the one hand it is traditional, religious, but on the other rapidly growing, attractive for business and has a free market.

3) Ukraine - Poland is a modern country, democratic, fast-growing, with a good organization of work.

4) Sweden, Portugal - knowledge about Poland is small, lack of distinctive image of the country.

Up to $43 \%$ of the Dutch, $31 \%$ of Russians, $29 \%$ of Britons, $28 \%$ of the French, and $20 \%$ of Germans had no concrete associations with Poland.

\section{European Place Marketing Institute}

In 2011, the European Place Marketing Institute conducted a survey on the image and promotion of Poland among 14 experts in the field of place branding mainly from France, Germany, Spain, and the USA. The aim of this study was to assess the current image and promotional activities of Poland (Florek, Jankowska, 2012, p. 4).

Most experts associated Poland with the person of Pope John Paul II, Catholicism, conservatism, bureaucracy, and family. Abroad we are still perceived as a conservative country with traditional values. Poland is connected to the end of communism and strikes in 1980 for many participants of the study. Our country is also associated with shopping. Foreign experts particularly appreciate Polish food, especially dumplings and vodka. According to respondents, Poland is a cold country in Eastern Europe, but with great views. The most recognizable cities are Warsaw and Cracow. Unfortunately, Polish tourist infrastructure was assessed negatively in the study (Florek, Jankowska, 2012, pp. 5-12).

\section{Conclusions}

Poland is now a country without a clear and coherent image in the international arena. Recognition and knowledge about Poland abroad is generally low. In the opinion of the citizens of Western European countries, Poland is a place with a backward civilization and is not very modern but is now quickly making up for "lost time". Polish products are not very competitive and are low-tech. Former CIS citizens identify Poland as modern and fast growing, and Polish products as attractive. Differences in stereotypes depend on the situation in the country of the respondent, which apparently is a reference at the time of expression of subjective opinions on Poland. 
Poland is seen by the citizens of different nationalities in some respects in a similar way - Poland is a hospitable, cheap, beautiful country with good cuisine and traditions. It should be emphasized that each year there is a continuous improvement of the image of Poland, which is increasingly recognized as a place that was able to take its chances and embark on a sustainable path of economic development.

Unfortunately, Poland is treated as a product of the "low-end" on the tourist market. Poland is not fashionable. It is still not an attractive tourist destination. This situation is caused by several circumstances. One of the most important factors is out of a man's reach - the weather. Unfortunately, there is an "encoded" conviction especially among Western Europeans that Poland is "a gray country" located somewhere in Eastern Europe, where there is no sunshine, and there is nothing interesting.

In Poland, we have no integrated system of building the country's image in the international arena. As confirmed by the results of the research, the majority of promotional activities carried out so far is not very effective. Lack of consistency in the activities of the institutions involved in the promotion of Poland leads to information noise, resulting in worse country's image than it is in reality. The country has an enormous potential to revive tourism which is still under-utilized. The prerequisite is to develop and implement a strategy for the development of tourism in 2016 which would take into account the exchange of information and coherence in the activities of the institutions responsible for the promotion of Poland abroad. Promotional message should better reflect the real strengths of the country and be more intense.

\section{References}

1. Analiza wyników badań wizerunku Polski i postrzegania polskiej marki na świecie. Założenia i rekomendacje do pozycjonowania Polski jako kraju docelowego podróży turystycznych na lata 2009-2015, Instytut Marki Polskiej, Warszawa, 2008.

2. Badania rozpoznawalności Polski na rynkach zagranicznych, Polska Organizacja Turystyczna, Warszawa, 2008.

3. Badania wizerunkowe Polski i polskiej gospodarki w krajach głównych partnerów gospodarczych, Raport z badań desk-research, Ageron Polska (Projekt realizowany na zlecenie Ministerstwa Gospodarki), Warszawa, 2011.

4. Bieger T., Management von Destination und Tourismusorganisation. - 2 Aufl. München, Wien/A, 1997.

5. Florek M., Jankowska M., Eye on Poland's Promotion. The promotion and image of Poland in the eyes of international place marketing experts, European Place Marketing Institute, 2012.

6. Fomina J., Konieczna-Sałamatin J., Kucharczyk J., Wenerski Ł., Poland-Ukraine, Poles-Ukrainians Look Across the Border, Institute of Public Affairs, Warsaw, 2013.

7. Gorbaniuk O., Radman D., Struktura wizerunku kraju i jej pomiar, Studia Socjologiczne 2011, Vol. 203, No. 4.

8. Strategia komunikacji na rynkach: brytyjskim, niemieckim i francuskim. Diagnoza oraz raport z badań jakościowych, Ageron Polska i Ageron Internacional S.L. na zlecenie Polskiej Organizacji Turystycznej, Warszawa, 2010.

9. Szmit B., Proces kreowania wizerunku Polski-analiza sytuacji i wytyczne dla dalszego rozwoju, Teraz Polska Promocja - tom 2, Fundacja Polskiego Godła Promocyjnego, Warszawa, 2010. 
10. Ustawa z dnia 25 czerwca 1999 r. o Polskiej Organizacji Turystycznej (Dz. U. z 1999 r., nr 62, poz. 689).

11. Ustawa z dnia 4 września 1997 r. o działach administracji rządowej (Dz. U. z 2007 r., nr 65, poz. 437).

12. Warchala M., Polska-Francja, Wzajemny wizerunek w okresie rozszerzania Unii Europejskiej, Instytut Spraw Publicznych, Warszawa, 2001.

\section{The Image of Poland as a Tourist Destination in the Country's Main Economic Partners}

Abstract. The aim of the study is to determine the current image of Poland in the countries covered by the research of the Ministry of Economy that are important from an economic point of view. To achieve the article's aim, we used Poland's image studies, carried out by public and private research institutions.

Poland is now a country without a clear and coherent image. The country is hospitable, cheap, with good cuisine, traditions, but still not an attractive tourist destination. The condition for the recovery of tourism is to develop and implement a strategy for the development of tourism from 2016 which would take into account the exchange of information and coherence in activities of the institutions responsible for the promotion of Poland abroad.

\section{Wizerunek Polski jako destynacji turystycznej w krajach głównych partnerów gospodarczych}

Abstrakt. Celem opracowania jest określenie aktualnego wizerunku Polski w krajach objętych badaniami Ministerstwa Gospodarki, istotnych z gospodarczego punktu widzenia. Do realizacji celu artykułu wykorzystano badania wizerunkowe Polski, przeprowadzone przez publiczne i prywatne instytucje badawcze.

Polska jest obecnie krajem bez wyraźnego i spójnego wizerunku. To kraj gościnny, tani, z dobrą kuchnią, tradycjami, wciąż jednak nie stanowi atrakcyjnej destynacji turystycznej. W Polsce nie ma zintegrowanego systemu budowania wizerunku kraju na arenie międzynarodowej. Warunkiem ożywienia ruchu turystycznego jest opracowanie i wdrożenie strategii rozwoju turystyki od 2016 roku, która uwzględniałaby wymianę informacji i spójność w działaniach instytucji odpowiedzialnych za promocję Polski za granicą. 